\title{
Reflux gastritis: distinct histopathological entity?
}

\author{
MF DIXON,* HJ O'CONNOR, $†$ ATR AXON, $\dagger$ RFJG KING, $\ddagger$ D JOHNSTON $\ddagger$
}

From the University Departments of *Pathology and $\ddagger$ Surgery, and the $\dagger$ Gastroenterology Unit, General Infirmary at Leeds, Leeds

SUMMARY A total of 98 patients who had either undergone gastric surgery (23) or who had peptic ulcers (56), or who had normal endoscopic findings (19), all underwent gastric biopsy, together with measurement of $\mathrm{pH}$ and total bile acid concentration in their fasting gastric juice. The biopsy specimens were graded "blind" for the presence of foveolar hyperplasia; oedema and smooth muscle fibres in the lamina propria; vasodilation and congestion of superficial mucosal capillaries; and a paucity of both acute and chronic inflammatory cells in the belief that these features constituted a distinctive histological picture related to reflux of alkaline duodenal content into the stomach.

We found a strong association between severe grades of each of these histological variables and both hypochlorhydria $(\mathrm{pH} \geqslant 4)$ and increased bile acid concentrations in the stomach. Furthermore, when the individual grades were added together to give a composite "reflux score," there was a significant difference in the incidence of hypochlorhydria $(p<0.01)$ and raised bile acid concentrations $(p<0.005)$ between those patients with a reflux score above and below 10. Although we do not claim that reflux is invariably accompanied by a distinctive histological picture, we suggest that recognition of this hitherto poorly documented combination of features as reflux gastritis may assist in the selection of patients for specific treatment and minimise the overdiagnosis of premalignant dysplasia (with which the lesion may be confused) in the postoperative stomach.

Histopathologists generally distinguish three main types of non-specific gastritis-namely chronic superficial, chronic atrophic, and acute gastritis; acute gastritis is often attributed to damage by drugs or alcohol, and is commonly described as "erosive". Although the concept of alkaline reflux gastritis has been gaining clinical acceptance, ${ }^{1}$ there is little awareness among histopathologists that the syndrome may be accompanied by a distinctive histological picture. Over the past few years we have become increasingly impressed by the incidence of certain histological features seen in biopsy specimens from some patients, usually after gastric surgery, who have clinical and endoscopic evidence of bile reflux into the stomach. ${ }^{23}$ The principal histological feature in such cases is the finding of elongation, tortuosity, and hypercellularity of the gastric pits (foveolar hyperplasia), often giving the mucosa a villous appearance. Other changes usually accompany this hyperplasia, however-namely, vasodilatation and congestion of capillaries in the

Accepted for publication 8 January 1986 superficial lamina propria; oedema and increased numbers of smooth muscle fibres in the lamina propria; and a paucity of both chronic inflammatory cells and of neutrophil polymorphs. To corroborate these observations and to test whether or not the features are correlated with the degree of reflux of alkaline duodenal contents into the stomach, gastric biopsy specimens were taken from preoperative and postoperative patients, the histological changes graded, and the grades obtained compared with the bile acid concentrations and $\mathrm{pH}$ of gastric juice.

\section{Patients and methods}

Five groups of patients were studied (Table 1): patients with normal findings at fibreoptic endoscopy $(n=19)$, active benign gastric ulceration $(n=25)$, duodenal ulceration $(\mathrm{n}=16)$, combined duodenal ? and gastric ulceration $(n=15)$, and a group of postoperative patients $(n=23)$ who had been treated surgically $1-40$ years previously (mean, 14.8 years); eight for duodenal ulceration or gastric ulceration, (seven duodenal ulceration, one gastric ulceration) by 524 
Table 1 Details of patients studied

\begin{tabular}{|c|c|c|c|c|c|c|}
\hline \multirow[t]{3}{*}{ Group } & \multicolumn{2}{|c|}{ No of patients } & \multicolumn{2}{|c|}{ Age (year) } & \multirow{2}{*}{\multicolumn{2}{|c|}{$\begin{array}{l}\text { Length of follow up } \\
\text { after operation (year) }\end{array}$}} \\
\hline & $\boldsymbol{M}$ & $F$ & Mean & Range & & \\
\hline & & & & & Mean & Range \\
\hline $\begin{array}{l}\text { Normal endoscopy } \\
\text { Duodenal ulcer } \\
\text { Gastric ulcer } \\
\text { Combined duodenal and gastric ulcer } \\
\text { Postoperative patients }\end{array}$ & $\begin{array}{r}10 \\
9 \\
12 \\
6 \\
19\end{array}$ & $\begin{array}{r}9 \\
7 \\
13 \\
9 \\
4\end{array}$ & $\begin{array}{l}41 \cdot 7 \\
44 \cdot 4 \\
62 \cdot 9 \\
54 \cdot 5 \\
56 \cdot 9\end{array}$ & $\begin{array}{l}22-75 \\
21-76 \\
36-83 \\
37-77 \\
26-78\end{array}$ & $14 \cdot 8$ & $1-40$ \\
\hline
\end{tabular}

Billroth I and seven (duodenal ulceration) by Billroth II partial gastrectomy, six (duodenal ulceration) by truncal vagotomy and gastroenterostomy, and two (gastric ulceration) who had undergone truncal vagotomy and antrectomy. None of the patients was on $\mathbf{H}_{2}$ receptor antagonist treatment at the time of the study. All the patients were undergoing oesophagogastroduodenoscopy after an overnight fast as part of routine gastrointestinal investigations and gave informed written consent to the procedure.

\section{SAMPLING TECHNIQUE AND SITES OF BIOPSIES} At endoscopy a sterile Teflon cannula was passed down the suction and biopsy channel of the endoscope, and $10-20 \mathrm{ml}$ of fasting gastric juice was aspirated for measurement of $\mathrm{pH}$ and total bile acid concentration. Four gastric mucosal biopsy specimens were then taken from the area within $5 \mathrm{~cm}$ of the pylorus in the non-operated patients and within $5 \mathrm{~cm}$ of the stoma in the operated group. Additional specimens were taken from any pathological lesions seen.

\section{HISTOLOGICAL ASSESSMENT OF GASTRIC}

MUCOSAL BIOPSY SPECIMENS

The biopsy specimens were orientated on filter paper and immediately fixed in formol saline. Paraffin processed sections were cut at three levels, stained by haematoxylin and eosin, and an additional section at the second level was stained with alcian blue, $\mathrm{pH} 2.5$ and periodic acid Schiff. The sections were examined by one of us (MFD), who was unaware of either the patients' endoscopic findings, gastric $\mathrm{pH}$, or bile acid concentrations. A score from 0 (normal or absent) to 3 (severe) was allotted for each of the following histological features according to its severity: foveolar hyperplasia, oedema and smooth muscle fibres in the

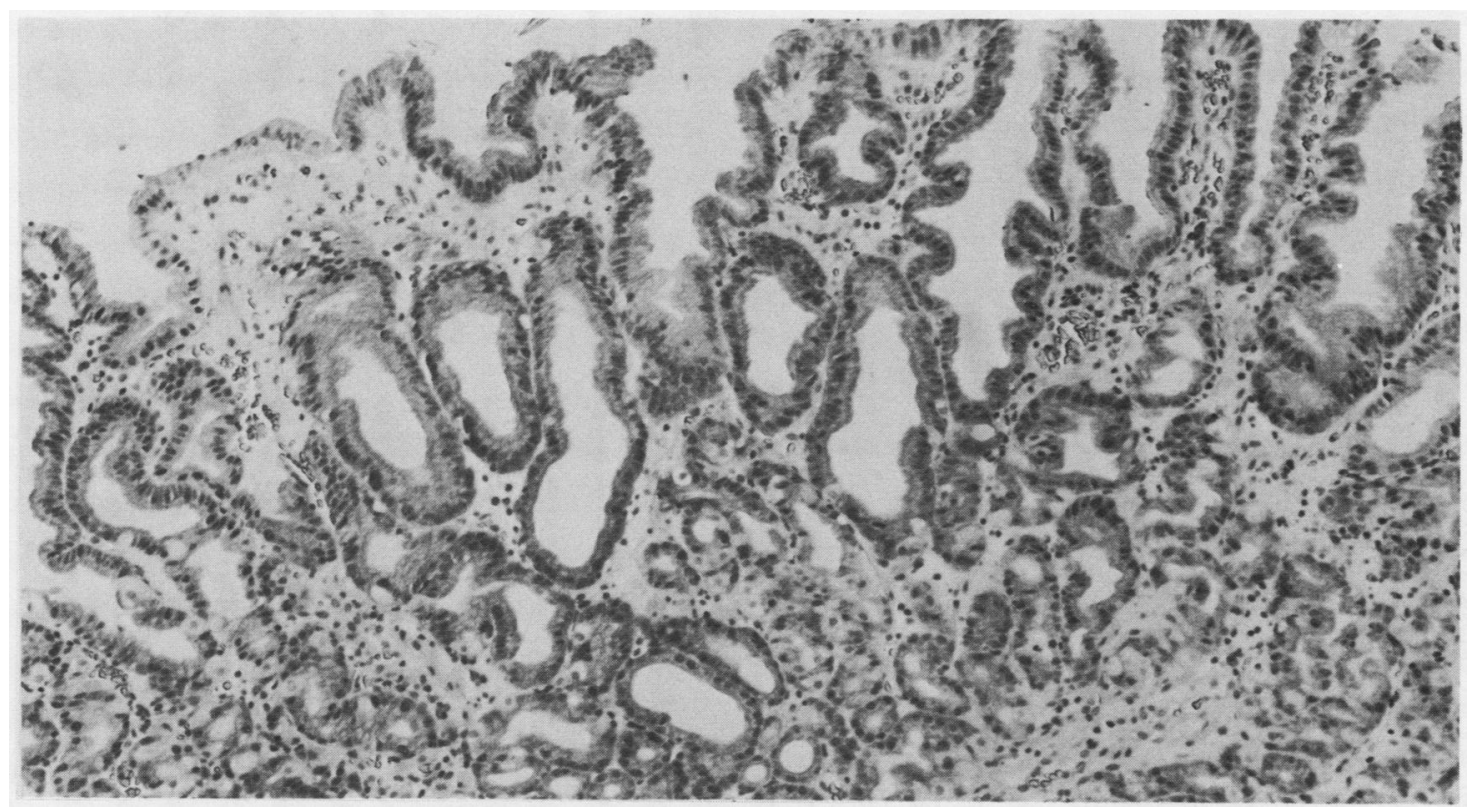

Fig. 1 Gastric biopsy specimen showing enlargement and tortuosity of the foveolae (grade 3), giving a villous appearance in places. There is no increase in acute (3) or chronic inflammatory cells (3). (Haematoxylin and eosin.) $\times 112$. 


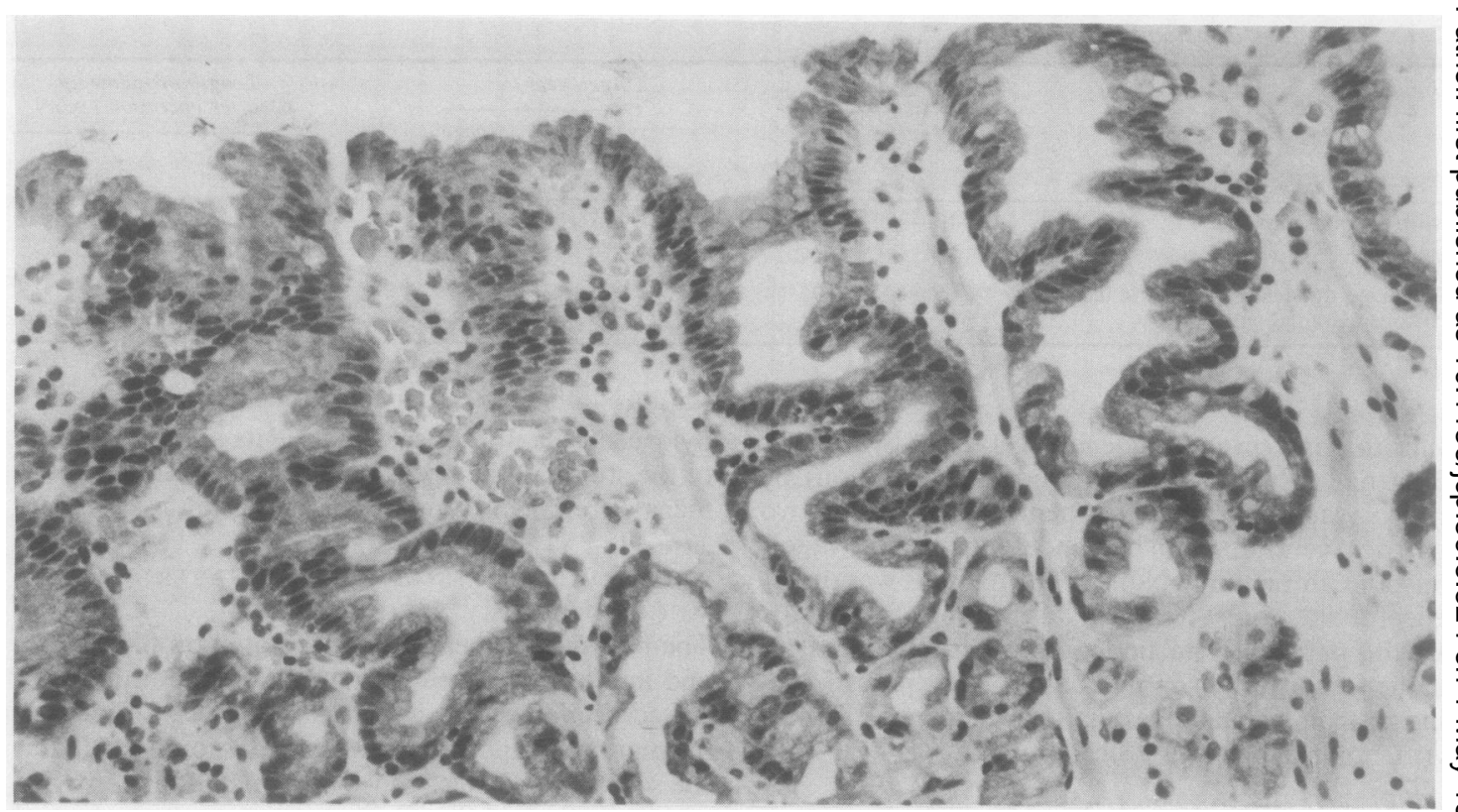

Fig. 2 Biopsy specimen showing marked foveolar hyperplasia (grade 3), moderate oedema and smooth muscle fibres in the lamina propria (2), severe capillary congestion (3), paucity of chronic inflammatory cells (3), and absence of polymorphs (3). (Haematoxylin and eosin.) $\times 224$.

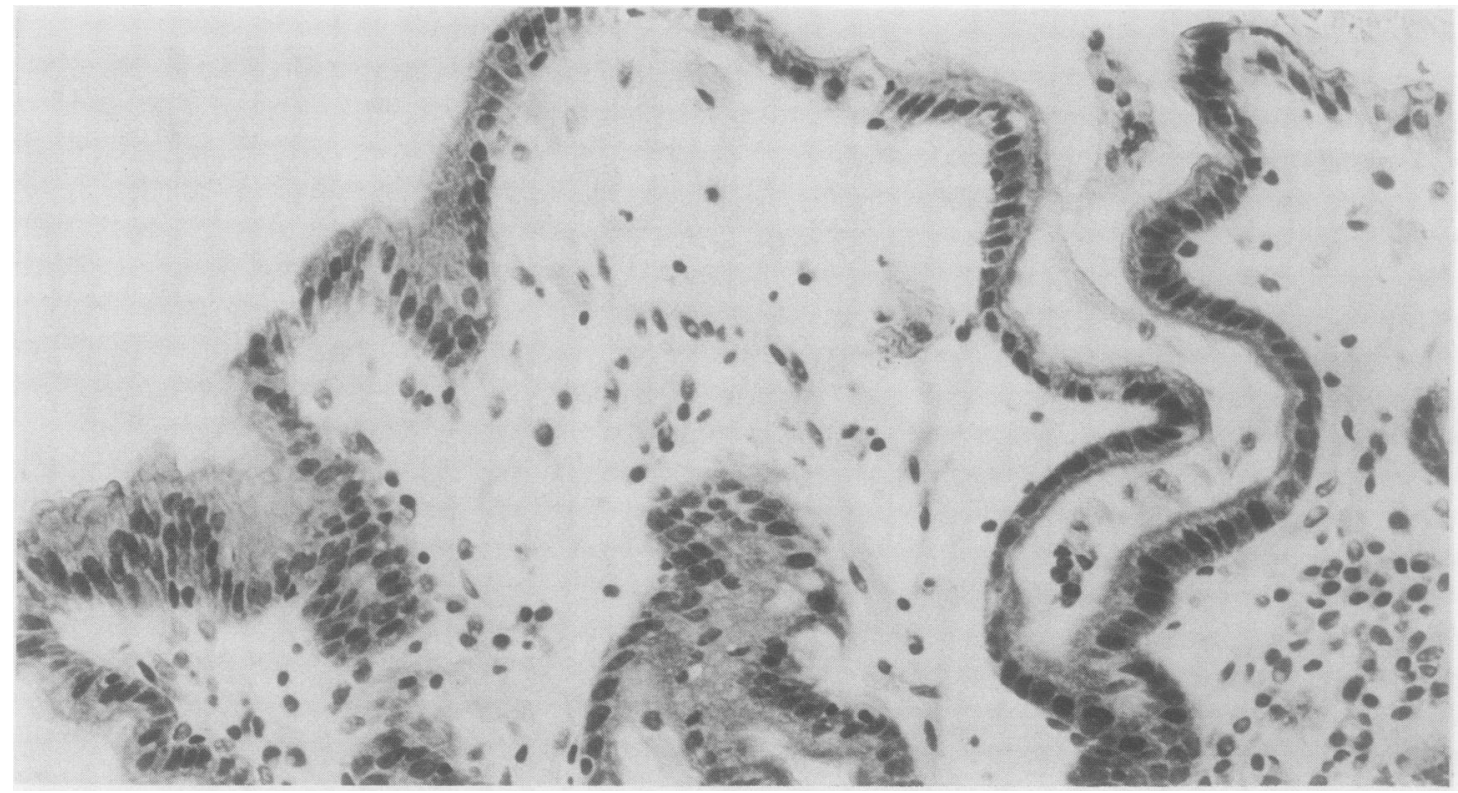

Fig. 3 In this biopsy specimen there is striking lamina propria oedema (grade 3), severe foveolar hyperplasia (3), and slight increase in chronic inflammatory cells (2), but absent polymorphs (3). Capillary congestion was seen elsewhere in specimen. (Haematoxylin and eosin.) $\times 280$. 
Table 2 Severity of reflux gastritis

\begin{tabular}{lll}
\hline Group & $\begin{array}{l}\text { No of } \\
\text { patients }\end{array}$ & $\begin{array}{l}\text { Reflux gastritis } \\
\text { score }\end{array}$ \\
\hline Normal endoscopy & 18 & $9 \cdot 4(2 \cdot 7)$ \\
Duodenal ulcer & 15 & $7 \cdot 9(2 \cdot 1)$ \\
Gastric ulcer & 25 & $8.9(3 \cdot 1)$ \\
Combined duodenal and gastric & 15 & $8.4(3.6)$ \\
$\quad$ ulcer & 22 & $12.0(3 \cdot 2)$ \\
\hline
\end{tabular}

*Mean (1 SD)

lamina propria, and vasodilatation and congestion of the lamina propria. Acute and chronic inflammatory cells were graded separately and given scores which reflected their paucity - that is, 0 (severe increase) to 3 (absence of polymorphs or normal or reduced numbers of chronic inflammatory cells). A combined score for paucity of inflammatory cells (minimum $=0$, maximum score $=6$ ) was given to each patient. Figs. 1-3 give examples of histological grading. A composite reflux gastritis score was calculated for each patient by simply adding the scores allotted for each of the individual variables (minimum score, 0 ; maximum score, 15). Those patients showing intestinal metaplasia in any of their biopsy specimens were noted.

MEASUREMENT OF GASTRIC PH AND BILE ACIDS The $\mathrm{pH}$ of the gastric aspirate was measured in all 98 patients with a combined glass electrode (Phillips) calibrated at pH 4 and 7. Hypochlorhydria was defined as a fasting intragastric $\mathrm{pH} \geqslant 4$. Total bile acid concentrations were measured in 75 patients using the steroid dehydrogenase method. ${ }^{4}$ The assay is based on the activity of a non-specific $3 \alpha$-hydroxysteroid dehydrogenase correlated to the reduction of nicotinamide adenine dinucleotide (NAD+) by the method we have previously described. ${ }^{5}$ The coefficient of variation between assays using this technique was $5 \%$. A bile acid concentration $>1 \mathrm{mmol} / \mathrm{l}$ was considered to be abnormal and indicative of clinically important enterogastric reflux. ${ }^{6}$ The values of bile acid concentrations reported represent the means of duplicate determinations on each sample.

STATISTICAL METHODS

Differences between the groups in gastric $\mathrm{pH}$, bile acid

Table 3 Fasting intragastric $p H$

\begin{tabular}{lll}
\hline Group & No of patients & $p H^{*}$ \\
\hline Normal endoscopy & 18 & $2 \cdot 1(0 \cdot 5)$ \\
Duodenal ulcer & 15 & $1 \cdot 9(0 \cdot 5)$ \\
Gastric ulcer & 25 & $2 \cdot 7(1 \cdot 3)$ \\
Combined duodenal and gastric ulcer & 15 & $2 \cdot 0(0 \cdot 4)$ \\
Postoperative patients & 22 & $6 \cdot 0(1 \cdot 8)$ \\
\hline *Mean (1 SD) & &
\end{tabular}

concentrations and reflux gastritis scores were analysed by the Wilcoxon rank sum test for significance, and the relation between $\mathrm{pH}$, bile acid concentrations, and reflux gastritis scores in the patient population as a whole was analysed by the $\chi^{2}$ test and Spearman's rank correlation test.

\section{Results}

\section{HISTOLOGICAL ASSESSMENT OF THE GASTRIC BIOPSY SPECIMENS}

The biopsy specimens from intact stomachs were invariably of antral mucosa. In the postoperative group 13 were of body type, six antral, and four intermediate. Three patients (one normal endoscopy, one duodenal ulceration, one postoperative) had normal histological findings and were thus excluded from further analysis. Table 2 shows the mean scores for reflux gastritis in each group of patients. Scores were highest in the postoperative patient group and lowest in the duodenal ulceration group. The mean reflux gastritis score was significantly higher in the postoperative patient group compared with that of the normal endoscopy group $(p<0.05)$, duodenal ulceration $(p<$ $0.01)$, gastric ulceration $(p<0.01)$, and duodenal ulceration and gastric ulceration group $(p<0.01)$. Differences in the degree of reflux gastritis between the normal endoscopy, duodenal ulceration, gastric ulceration, and combined duodenal and gastric ulceration groups were not significant.

GASTRIC PH AND BILE ACID CONCENTRATIONS Tables 3 and 4 show fasting intragastric $\mathrm{pH}$ and bile acid concentrations, respectively, in the five groups of patients. Mean $\mathrm{pH}$ in the postoperative patient group was significantly higher than in the normal, duodenal ulceration, gastric ulceration, and combined duodenal and gastric ulceration groups $(p<0.01)$. Patients in the postoperative patients group also had significantly higher fasting bile acid concentrations in the stomach than did patients in the normal ( $p<0.05)$, duodenal ulceration ( $p<0.01)$, gastric ulceration $(p<0.01)$, and combined duodenal and gastric ulceration $(\mathrm{p}<$ $0.01)$ groups. Of the 75 patients who had both gastric $\mathrm{pH}$ and bile acid concentrations measured, there was a highly significant correlation between hypo-

Table 4 Fasting bile acid concentrations in the stomach

\begin{tabular}{|c|c|c|}
\hline Group & $\begin{array}{l}\text { No of } \\
\text { patients }\end{array}$ & $\begin{array}{l}\text { Fasting bile acid } \\
\text { concentrations }(\mathrm{mmol} / \mathrm{l})^{*}\end{array}$ \\
\hline $\begin{array}{l}\text { Normal endoscopy } \\
\text { Duodenal ulcer } \\
\text { Gastric ulcer } \\
\text { Combined duodenal and } \\
\text { gastric ulcer } \\
\text { Postoperative patients }\end{array}$ & $\begin{array}{l}13 \\
10 \\
19 \\
\\
12 \\
18\end{array}$ & $\begin{array}{l}0.10(0.32) \\
0.11(0.25) \\
0.51(2.04) \\
0.11(0.22) \\
5.88(6.67)\end{array}$ \\
\hline
\end{tabular}


Table 5 Gastric pH, bile acid concentrations, and severity of individual histological variables

\begin{tabular}{|c|c|c|c|c|c|c|c|c|c|c|c|c|}
\hline & \multicolumn{3}{|c|}{$\begin{array}{l}\text { Foveolar hyperplasia } \\
\text { Grade }\end{array}$} & \multicolumn{3}{|c|}{$\begin{array}{l}\text { Oedema and smooth muscle } \\
\text { fibres in lamina propria } \\
\text { Grade }\end{array}$} & \multicolumn{3}{|c|}{$\begin{array}{l}\text { Vasodilatation congestion of } \\
\text { lamina propria } \\
\text { Grade }\end{array}$} & \multicolumn{3}{|c|}{$\begin{array}{l}\text { Paucity of acute and } \\
\text { chronic inflammatory cefy } \\
\text { Grade }\end{array}$} \\
\hline & 3 & $<3$ & & 3 & $<$ & & 3 & $<$ & & $\geqslant 4$ & $<4$ & $\frac{5}{0}$ \\
\hline $\begin{array}{r}\text { Gastric } \\
\geqslant 4 \\
<4\end{array}$ & $\begin{array}{r}\text { pH } \\
14 \\
20\end{array}$ & $\begin{array}{r}9 \\
52\end{array}$ & $\begin{array}{l}\chi^{2}=8.306 \\
\mathbf{p}<0.005\end{array}$ & $\begin{array}{l}10 \\
11\end{array}$ & $\begin{array}{l}13 \\
61\end{array}$ & $\begin{array}{l}\chi^{2}=8.051 \\
\mathrm{p}<0.005\end{array}$ & $\begin{array}{l}12 \\
21\end{array}$ & $\begin{array}{l}11 \\
51\end{array}$ & $\begin{array}{l}\chi^{2}=4.070 \\
\mathrm{p}<0.05\end{array}$ & $\begin{array}{l}15 \\
29\end{array}$ & $\begin{array}{r}8 \\
43\end{array}$ & $\begin{array}{l}\chi^{2}=4.30 \\
\mathrm{p}<0.09\end{array}$ \\
\hline $\begin{array}{r}\mathbf{B A C} \mathbf{C}^{\star} \\
\geqslant 1 \\
<1\end{array}$ & $\begin{array}{r}\mathrm{mmol} / \mathrm{l}) \\
9 \\
17\end{array}$ & $\begin{array}{r}6 \\
40\end{array}$ & $\begin{array}{l}\chi^{2}=4.687 \\
\mathrm{p}<0.05\end{array}$ & $\begin{array}{l}7 \\
9\end{array}$ & $\begin{array}{r}8 \\
48\end{array}$ & $\begin{array}{l}\chi^{2}=6.550 \\
\mathrm{p}<0.02\end{array}$ & $\begin{array}{r}9 \\
17\end{array}$ & $\begin{array}{r}6 \\
40\end{array}$ & $\begin{array}{l}\chi^{2}=4.687 \\
p<0.05\end{array}$ & $\begin{array}{l}11 \\
20\end{array}$ & $\begin{array}{r}4 \\
37\end{array}$ & $\begin{array}{l}\chi^{2}=7.08 \\
\mathfrak{p}<0.01\end{array}$ \\
\hline
\end{tabular}

chlorhydria and increased bile acid concentrations $(\geqslant 1 \mathrm{mmol} / \mathrm{l})$ in the stomach $\left(\chi^{2}=53.42, \mathrm{p}<0.001\right)$. This correlation remained significant when patients with intestinal metaplasia $(n=27)$, another variable which may be associated with raised gastric $\mathrm{pH}$, were excluded from analysis $\left(\chi^{2}=26.02, \mathrm{p}<0.001\right)$.

\section{GASTRIC PH, BILE ACID CONCENTRATIONS, AND REFLUX GASTRITIS}

Table 5 shows the relation between the graded severity of foveolar hyperplasia, oedema and smooth muscle infiltration of the lamina propria, vascular dilatation and congestion of the lamina propria, paucity of acute and chronic inflammatory cells, and both gastric $\mathrm{pH}$ and degree of reflux of bile acids. A significant correlation was found between severe change in each of the histological variables and both hypochlorhydria and increased concentration of bile acids in the stomach. Furthermore, when the composite reflux gastritis scores were compared with gastric $\mathrm{pH}$ and the degree of reflux of bile acids (Table 6), there was a significant association between severe reflux gastritis and both hypochlorhydria and high bile acid concentrations in the stomach. Of the 36 patients with a reflux gastritis score $>10,14$ had a gastric $\mathrm{pH} \geqslant 4$, whereas only nine of 59 patients with a score $\leqslant 10$ were hypochlorhydric $(p<0.01)$. Likewise, of the 72 patients who had bile acid concentrations measured, 27 had a reflux gastritis score $>10$, and 11 of these patients had bile acid concentrations $\geqslant 1 \mathrm{mmol} / \mathrm{l}$, whereas of the $\mathbf{4 5}$ patients with a score of $\leqslant 10$, only four had abnormally high bile acid concentrations $(p<0.005)$. Furthermore, when the relation between reflux gas- tritis score and $\mathrm{pH}$ and bile acid concentrations was examined using Spearman's rank correlation test, significant correlations were achieved (reflux gastritis $v \mathrm{pH}=0.2709, \mathrm{p}<0.01$; reflux gastritis $v$ bile acid concentrations $=0.2655, \mathrm{p}<0.05$ ).

\section{Discussion}

Although the widespread adoption of Whitehead's classification ${ }^{7}$ brought much needed order to the histological diagnosis of chronic gastritis, strict adherence to it seems to have inhibited the recognition of reflux gastritis as a separate entity. The few studies in which an attempt has been made to relate the histological findings in endoscopic biopsies to intragastric bile acids have almost invariably used chronic inflammatory cell infiltration and grades of chronic superficial and chronic atrophic gastritis for purposes of comparison..$^{8-11}$ It does not surprise us, therefore, that others have found a poor correlation between histology and bile reflux ${ }^{812}$ and that measures which brought about a reduction in intragastric bile were not accompanied by improvement in the histological findings when assessed in this way. ${ }^{910}$

This study has shown that a histological picture quite distinct from previously described categories of gastritis, comprising foveolar hyperplasia, oedema and increased smooth muscle fibres in the lamina propria, capillary congestion, and a relative paucity of acute and chronic inflammatory cells, is strongly associated with raised intragastric bile acid concentrations and increased $\mathrm{pH}$.

Table 6 Gastric pH, bile acid concentrations, and severity of reflux gastritis

\begin{tabular}{|c|c|c|c|c|}
\hline $\begin{array}{l}\text { Reflux } \\
\text { gastritis }\end{array}$ & & Gastric $p H$ & & $\begin{array}{l}\text { Bile acid concentrations } \\
(\text { mmol } / l)\end{array}$ \\
\hline $\begin{array}{l}>10 \\
\leqslant 10\end{array}$ & $\begin{array}{l}\geqslant 4 \\
<4\end{array}$ & $\left.\begin{array}{rr}14 & 9 \\
20 & 52\end{array}\right\} \chi^{2}=6.806 \mathrm{p}<0.01$ & $\geqslant 1$ & $\left.\begin{array}{lr}11 & 4 \\
16 & 41\end{array}\right\} x^{2}=10.380 \mathrm{p}<0.005$ \\
\hline
\end{tabular}


The use of gastric juice $\mathrm{pH}$ as an index of alkaline reflux may be called into question. Although we have shown a highly significant correlation between hypochlorhydria $(\mathrm{pH} \geqslant 4)$ and raised bile acid concentrations, it might be argued that increased alkalinity is more likely to result from a long term reduction in Gcell and parietal cell activity brought about by chronic atrophic gastritis, rather than a short term effect of alkaline reflux. When those patients exhibiting intestinal metaplasia (a "marker" of chronic atrophic gastritis) were eliminated, however, there remained a highly significant association between hypochlorhydria and raised bile acid concentrations. Furthermore, in grading the biopsy specimens for a paucity of chronic inflammatory cells we biased the reflux gastritis score against coexistent chronic atrophic gastritis.

In proposing that the combination of histological features we found in association with alkaline reflux constitutes a distinct entity, we should emphasise that several previous studies have drawn attention to one or more of the individual features we describe. These observations, however, seem to have had little impact on histopathological practice.

Most emphasis has been given to foveolar hyperplasia, and this feature has been documented in both experimental ${ }^{13-16}$ and clinical studies. ${ }^{17-19}$ Such hyperplasia, however, has been regarded as either part of chronic superficial gastritis (albeit a prominent part), or as a change associated with focal ulceration and haemorrhage in an erosive gastritis. ${ }^{17}$ To our knowledge no one has drawn attention to the severe and unusual discrepancy between the prominent epithelial and the minimal or absent inflammatory cell response found in reflux gastritis. Previous workers have invariably sought an increase in inflammatory cells to parallel the observed foveolar hyperplasia. For example, Mosimann et al, in a clinical study on enterogastric reflux after duodenal ulcer surgery, ${ }^{20}$ continued to grade chronic inflammation and atrophy despite establishing in earlier work that the number of inflammatory cells was an unreliable criterion for the diagnosis of reflux gastritis. ${ }^{2122}$

Perhaps more surprising has been the reluctance of histopathologists to accept that the vascular component of an inflammatory reaction-namely, capillary congestion and lamina propria oedema, can be genuine features of a gastritis without a concomitant increase in inflammatory cells. It is surprising because "hyperaemia" has been one of the hallmarks of the endoscopic diagnosis of reflux gastritis ${ }^{8121923}$ and although occasional histological descriptions have mentioned congestion and oedema, ${ }^{1723}$ these features have never been graded as part of a reflux gastritis.

We do not, of course, claim specificity for the individual histological features seen in reflux. Foveolar hyperplasia is simply a response to excessive cell exfoliation from the surface epithelium and as such is seen in all types of active gastritis. Likewise, hyperaemia and oedema are part of any inflammatory process. Nor do we claim that these features invariably accompany reflux. In keeping with the multifactorial causation of chronic gastritis, biopsy specimens showing increased numbers of chronic inflammatory cells in either a chronic superficial, or chronic atrophic gastritis, may also be obtained from patients with reflux of duodenal content into the stomach. ${ }^{23}$ What we would claim is that the finding of severe degrees of hyperplasia, capillary dilatation and congestion, and lamina propria oedema, with no increase in chronic inflammatory cells, is highly suggestive of reflux gastritis.

The importance of making this diagnosis is two fold. Firstly, it would greatly assist in the selection of those patients who are likely to benefit from treatment with bile binding compounds or diversionary surgery. Secondly, the finding of severe foveolar hyperplasia in the absence of an inflammatory cell response is liable to be misinterpreted as premalignant dysplasia and may have serious consequences for the patient in terms of inappropriate surgery, or at least, in unnecessary endoscopies and repeat biopsies.

\section{References}

${ }^{1}$ Ritchie WP. Alkaline reflux gastritis: a critical appraisal. Gut 1984;25:975-87.

${ }^{2}$ Dewar EP, Dixon MF, Johnston D. Bile refiux and degree of gastritis after highly selective vagotomy, truncal vagotomy, and partial gastrectomy for duodenal ulcer. World J Surg 1983; 7:743-50.

${ }^{3}$ Dewar EP, Dixon MF, Johnston D. Bile reflux and degree of gastritis in patients with gastric ulcer: before and after operation. $J$ Surg Res 1984;37:277-84.

4 Fausa O, Skalhegg BA. Quantitative determination of bile acids and their conjugates using thin layer chromatography and a purified $3 \alpha$-hydroxysteroid dehydrogenase. Scand J Gastroenterol 1974;9:249-54.

${ }^{5}$ Dewar EP, King RFG, Johnston D. Bile acid and lysolecithin concentrations in the stomach of patients with gastric ulcer: before operation and after treatment by highly selective vagotomy, Billroth I partial gastrectomy and truncal vagotomy and pyloroplasty. Br J Surg 1983;70:401-5.

${ }^{6}$ Rhodes J, Barnado DE, Phillips SF, Rovelstad PA, Hofmann AF. Increased reflux of bile into the stomach in patients with gastric ulcer. Gastroenterology 1969;57:241-52.

${ }^{7}$ Whitehead R, Truelove SC, Gear MWL. The histological diagnosis of chronic gastritis in fibreoptic gastroscope biopsy specimens. $J$ Clin Pathol 1972;25:1-11.

${ }^{8}$ Keighley MRB, Asquith P, Alexander-Williams J. Duodenogastric reflux: a cause of gastric mucosal hyperaemia and symptoms after operation for peptic ulceration. Gut 1975;16:28-32.

${ }^{9}$ Hoare AM, McLeish A, Thompson H, Alexander-Williams J. Selection of patients for bile diversion surgery: use of bile acid measurement in fasting gastric aspirates. Gut 1978;19:163-5.

${ }^{10}$ Malagelada JR, Phillips SF, Higgins JA, Shorter RG, van Heerden JA, Adson MA. A prospective evaluation of alkaline reflux gastritis: bile acid binding agents and Roux-Y diversion. Gastroenterology 1979;76:1192. 
${ }^{11}$ Meshkinpour H, Marks JW, Schoenfield LJ, Bonnoris GG, Carter S. Reflux gastritis syndrome: mechanism of symptoms. Gastroenterology 1980;79:1283-7.

${ }^{12}$ Hoare AM, Jones EL, Alexander-Williams J, Hawkins CF. Symptomatic significance of gastric mucosal changes after surgery for peptic ulcer. Gut 1977;18:295-300.

${ }^{13}$ Lawson HH. The effect of the duodenal contents on the gastric mucosa under experimental conditions. $S$ Afr $J$ Surg 1965;3:79-92.

${ }^{14}$ Menguy R, Max MH. Influence of bile on the canine gastric-antral mucosa. Am J Surg 1970;119:177-82.

${ }^{15}$ Delaney JP, Broadie TA, Robbins PL. Pyloric reflux gastritis; the offending agent. Surgery 1975;77:764-72.

${ }^{16}$ Robbins PL, Broadie TA, Sosin H, Delaney JP. Reflux gastritis. The consequences of intestinal juice in the stomach. Am J Surg 1976;131:23-9.

${ }^{17}$ Drapanas T, Bethea M. Reflux gastritis following gastric surgery. Ann Surg 1974;179:618-27.

${ }^{18}$ Loup P, Fontolliet C, Gonvers JJ, et al. Realité de la gastrite postoperatoire par reflux. Schweiz Med Wochenschr 1978;108:1129-35.
19 Ritchie WP. Alkaline reflux gastritis. An objective assessment of its diagnosis and treatment. Ann Surg 1980;192:288-98.

${ }^{20}$ Mosimann F, Sorgi M, Wolverson RL, et al. Gastric histology and its relationship to entero-gastric reflux after duodenal ulcer surgery. Scand J Gastroenterol 1984;19(Suppl 92):142-4.

${ }^{21}$ Mosimann F, Burri B, Diserens $H$, Fontolliet C, Loup P, Mosimann R. Enterogastric reflux; experimental and clinical study. A preliminary report. Scand $J$ Gastroenterol 1981;16(Suppl 67):149-52.

${ }^{22}$ Mosimann R, Loup P, Fontolliet C, Mosimann F. Post-operative reflux gastritis. Results of surgical treatment. Scand J Gastroenterol 1981;16(Suppl 67):237-9.

${ }^{23}$ Scudamore HH, Eckstam EE, Fencil WJ, Jaramillo CA. Bile reflux gastritis. Diagnosis, medical and surgical therapy. Am J Gastroenterol 1973;60:9-22.

Requests for reprints to: Dr MF Dixon, Department of Pathology, University of Leeds, Leeds LS2 9JT, England. 